\title{
Ksiądz profesor Jerzy Chmiel a badania rękopisów z Qumran
}

Zdzisław J. Kapera

Kraków

enigma@post.pl

Ksiądz profesor Jerzy Chmiel wniósł niemały wkład do polskiej i światowej qumranologii, choć zapewne byłby zdziwiony określeniem go dzisiaj mianem qumranologa, ponieważ była to tylko jedna $\mathrm{z}$ wielu dziedzin biblistyki, którą się interesował. Chcąc wyjaśnić genezę jego zainteresowania tą wąską dyscypliną biblistyki, trzeba wspomnieć, że wśród jego profesorów w krakowskim seminarium duchownym był w latach pięćdziesiątych XX wieku ks. prof. Aleksy Klawek (1890-1969)를 który prezentował odkrycia w Qumran w środowisku krakowskim i na łamach założonego przez siebie czasopisma „Ruch Biblijny i Liturgiczny” od 1949 roku - co prawda nie osobiście, choć ściągał z zagranicy i czytał bieżące publikacje, ale piórem swego ucznia ks. prof. Stanisława Grzybka (1915-1998)², który najpierw pomagał mu, a potem sam redagował krakowski periodyk biblijny. Ks. Jerzemu Chmielowi musiał być znany wydany w 1957 roku numer specjalny tego czasopisma ${ }^{3}-$ pierwsza całościowa prezentacja wyników badań na gruncie polskim, zanim wyjechał w roku 1961 do Rzymu celem pogłębienia studiów teologicznych. Studiował w Papieskim Uniwersytecie Gregoriańskim w latach 1961-1963 oraz w Papieskim Instytucie Biblijnym w latach

1 Por. R. Zimny, Całe życie z Biblia. Aleksy Klawek (1890-1969), Uniwersytet im. Adama Mickiewicza w Poznaniu Wydział Teologiczny, Poznań 2004.

2 Por. Z. J. Kapera, Qumranologia polska: dokonania i perspektywy, „Collectanea Theologica” 75 (2005) fasc. 3, s. 24-25 (na temat ks. Klawka) i s. 26-27 (na temat ks. Grzybka).

3 „Ruch Biblijny i Liturgiczny” 10 (1957) nr 6: Odkrycia nad Morzem Martwym (1947-1957), https://rbl.ptt.net.pl/index.php/RBL/issue/view/167. 
1963-1966. W międzyczasie poszerzał swoją wiedzę w Papieskim Instytucie Archeologii Chrześcijańskiej (1962) i w Schola Superior Litterarum Latinarum przy Uniwersytecie Gregoriańskim (1961-1963). Kolejne trzy lata spędził nad przygotowaniem doktoratu z teologii na tym uniwersytecie ${ }^{4}$. W sumie osiem lat pobytu w wiecznym mieście pozwoliło wzmocnić zamiłowanie ks. Chmiela do archeologii i realiów biblijnych, chłonąć klimat Kościoła w dobie aggiornamento i poznawać wielu luminarzy nauk biblijnych, wśród których musiał także zwrócić jego uwagę ks. Józef Tadeusz Milik, często podówczas przebywający w Rzymie w związku z przygotowaniem kolejnych publikacji rękopisów qumrańskich ${ }^{5}$. Choć ks. Chmiel nigdy nie chwalił się osobistą z nim znajomością, to jednak jego uwagi na temat pozycji naukowej i sytuacji osobistej ks. Milika w latach sześćdziesiątych, które poruszył w czasie dyskusji po moim referacie nt. Milika jako współtwórcy qumranologii wygłoszonym w roku 2003 w Polskim Towarzystwie Teologicznym ${ }^{6}$, wskazują, że ich drogi w Rzymie musiały się nieraz skrzyżować. W każdym razie ks. Chmiel śledził dokonania naukowe Milika, wysoce je cenił i sam osobiście interesował się na bieżąco nowymi odkryciami nad Morzem Martwym. Świadczy o tym jego bibliografia za rok 1969 tuż po powrocie z Rzymu. ${ }^{7}$ W „Ruchu Biblijnym i Liturgicznym” zamieszcza krótki, pierwszy w języku polskim ${ }^{8}$ artykuł informacyjny na temat nowo pozyskanego Zwoju Świątyni ${ }^{9}$. I nawet w tej niewielkiej notce polemizuje z Yigaelem Yadinem, odrzucając jego tezę, że pisownia

4 Por. W. Chrostowski, Ks. Profesor Jerzy Chmiel, [w:] Pan moim świattem. Księga pamiątkowa dla Księdza Profesora Jerzego Chmiela w 65. rocznicę urodzin, red. W. Chrostowski, Vocatio, Warszawa 2000, s. 9-12.

5 Por. Z. J. Kapera, Józef Tadeusz Milik Doyen of the Dead Sea Scrolls, [w:] Z. J. Kapera, R. Feather, Doyen of the Dead Sea Scrolls. An in depth biography of Józef Tadeusz Milik (1922-2006), The Enigma Press, Kraków-Mogilany 2011, s. 71-74.

6 Z. J. Kapera, Józef Tadeusz Milik - wspóttwórca qumranologii, „Ruch Biblijny i Liturgiczny” 56 (2003) nr 1, s. 5-16, https://doi.org/10.21906/rbl.418.

7 Por. Bibliografia prac ks. prof. Jerzego Chmiela, [w:] Pan moim świattem..., dz. cyt., s. 13.

8 Pierwszy artykuł nt. Zwoju Świątyni pióra W. Tylocha, czołowego znawcy problematyki qumrańkiej w Polsce, ukazał się dopiero w roku 1980. Por. W. Tyloch, Le „Rouleau du Temple” et les Esséniens, „Rocznik Orientalistyczny” 41 (1980) z. 2, s. 139-143.

9 J. Chmiel, Nowe rękopisy z Qumran, „Ruch Biblijny i Liturgiczny” 22 (1969) nr 4-5, s. 302303, https://doi.org/10.21906/rbl.3228. 
imienia YHWH hebrajskim pismem kwadratowym miałaby świadczyć o kanoniczności rękopisu.

Ks. prof. Jerzego Chmiela poznałem wkrótce po jego powrocie z Rzymu. Zbliżył nas fakt, iż obaj byliśmy uczniami ks. prof. Aleksego Klawka, luminarza nauk biblijnych w Polsce, wyjątkowo utalentowanego hebraisty i teologa, uznanego znawcy i tłumacza psalmów, cenionego onomastyka biblijnego. Obaj uczestniczyliśmy w sesjach poświęconych jego pamięci i obaj pisaliśmy o nim. Ponieważ Komisja Orientalistyczna Krakowskiego Oddziału Polskiej Akademii Nauk utraciła nieszczęśliwie w roku 1969 swego członka ks. prof. Aleksego Klawka, reprezentującego nauki biblijne, a w roku 1972 - ks. doc. Ludwika Stefaniaka ${ }^{\mathbf{1 0}}$, to właśnie ks. prof. Jerzy Chmiel został powołany na członka Komisji, co pozwoliło nam owocnie współpracować w latach siedemdziesiątych, osiemdziesiątych i dziewięćdziesiątych ubiegłego stulecia. Byłem wówczas sekretarzem technicznym Komisji Orientalistycznej i sekretarzem rocznika „Folia Orientalia”. Ks. Chmiel natomiast został sekretarzem, a potem redaktorem naczelnym „Ruchu Biblijnego i Liturgicznego”11. Owocem naszej współpracy wydawniczej były dwa zeszyty specjalne tego dwumiesięcznika na temat ks. prof. Aleksego Klawka (w latach 1970 i 1980) ${ }^{12}$ oraz zeszyt poświęcony pamięci ks. Ludwika Stefaniaka (w roku 1973) ${ }^{13}$, a także tom Studia biblica Alexio Klawek oblata na łamach „Folia Orientalia” (za rok 1980). W związku z tą ostatnią publikacją chciałbym zacytować fragment jej omówienia na łamach „Ruchu Biblijnego i Liturgicznego”, gdyż dobrze oddaje on nastawienie

10 Por. Z. J. Kapera, Działalność naukowa ks. Ludwika Stefaniaka, CM (1930-1972), „Ruch Biblijny i Liturgiczny” 26 (1973) nr 2-3, s. 131-138, https://doi.org/10.21906/rbl.3540; Z. J. Kapera, The Rev. Ludwik Walenty Stefaniak, CM (1930-1972) the Promotor of Biblical Archaeology in Poland, „The Polish Journal of Biblical Research” 6 (2004), s. 99-111.

11 Por. S. Jędrzejewski, Powstanie i rozwój „Ruchu Biblijnego i Liturgicznego”, [w:] Sześćdziesiąt lat „Ruchu Biblijnego i Liturgicznego” w służbie odnowy biblijnej i liturgicznej w Polsce, red. S. Wronka, Wydawnictwo UNUM, Kraków 2007, s. 63-67, https://doi. org/10.21906/9788376431451.

12 Por. Śp. ks. prof. Aleksy Klawek (1890-1969), „Ruch Biblijny i Liturgiczny” 23 (1970) nr 6, s. 259-266, https://doi.org/10.21906/rbl.3261; „Ruch Biblijny i Liturgiczny” 33 (1980) nr 4, s. $181-232$.

13 Por. „Ruch Biblijny i Liturgiczny” 26 (1973) nr 2-3, s. 57-168. 
ks. Jerzego Chmiela do kolejnego etapu naszej współpracy związanej już z badaniami nad Qumran. Otóż pisał on tak:

Prezentowany rocznik „Folia Orientalia” - homagium krakowskiego ośrodka orientalistycznego, wraz z zaproszonymi biblistami, dla śp. ks. profesora Aleksego Klawka, biblisty i orientalisty - jest doskonałym przykładem interdyscyplinarnej współpracy naukowej, kiedy to wspólne poszukiwanie prawdy łączy różnych ludzi ponad kontynenty i trudności techniczne ${ }^{14}$.

Nie zapominajmy, że interdyscyplinarność i międzynarodowa współpraca ludzi nauki w poszukiwaniu prawdy nie była rzeczą łatwą w czasach komunistycznych. Należy tu pamiętać choćby o utrudnieniach paszportowych oraz braku dewiz na przyjazdy specjalistów z zagranicy. Dlatego z wdzięcznością wspominam, że dzięki ks. Chmielowi miałem okazję wziąć udział, chyba jako jedna z nielicznych osób świeckich, w Kongresie Biblijnym w Krakowie w czerwcu 1972 roku, gdzie z referatem na temat papirusów z groty 7 w Qumran wystąpił kard. Carlo M. Martini ${ }^{15}$. Jeden z tych papirusów hipoteza o. O’Callaghana wiązała z Ewangelią św. Marka, co stało się światową sensacją i - cytując słowa ks. Chmiela - „wywołała zrozumiałe poruszenie i dyskusję”16. Dodałbym: burzliwą dyskusję. Nic dziwnego, że już niecały rok później także ks. Jerzy Chmiel zabrał osobiście głos w sprawie papirusów groty 7. Omówił nie tylko stan badań nad nimi, ale także zastanawiał się nad aspektem paleograficznym, archeologicznym i historyczno-literackim tych tekstów. Trafnie zauważył, że akceptacja hipotezy o. O’Callaghana wiąże się z poszukiwaniem „takiej struktury znaków graficznych, która będzie najlepiej odpowiadać badanym fragmentom”. Zidentyfikował on bowiem „takie struktury tekstowe z Nowego Testamentu, aczkolwiek

14 J. Chmiel, Studia biblica Alexio Klawek oblata, Wrocław-Warszawa-Kraków-Gdańsk-Łódź 1981, „Ruch Biblijny i Liturgiczny” 35 (1982) nr 1, s. 61, https://doi.org/10.21906/rbl.1836.

15 C. M. Martini, I piu antichi documenti sull'origine del christianesimo, [w:] Materiały Kongresu Biblijnego w Krakowie, 6-8 czerwca 1972 r., oprac. S. Grzybek, J. Chmiel, Polskie Towarzystwo Teologiczne w Krakowie, Kraków 1974, s. 85-86.

16 J. Chmiel, Papirusy groty 7 z Qumran, „Ruch Biblijny i Liturgiczny” 26 (1973) nr 2-3, s. 95, https://doi.org/10.21906/rbl.3535. 
nie wolne od pewnych braków”. Jeśli jednak „ktoś znajdzie inne koherentne rozwiązanie, [to] wskaże tym samym lokalizację fragmentów (niekoniecznie biblijną w znaczeniu ksiąg kanonicznych)”. To spostrzeżenie po latach okazało się wyjątkowo prorocze. Dzięki badaniom pism apokryficznych, a poniekąd wprowadzeniu ich w obieg elektroniczny, uważa się dzisiaj, że być może mamy raczej do czynienia z tekstem Księgi Henocha niż z ułamkami pism Nowego Testamentu. Rozważając natomiast datowanie papirusów, ks. Jerzy Chmiel zwrócił uwagę, że materiał (papirus) i forma (zwój) rękopisów groty 7 wskazuje na wczesne datowanie tekstów, „przemawia za bardzo starochrześcijańskim pochodzeniem”. Uwzględniając aspekt archeologiczny ks. Jerzy Chmiel proponował konieczność zbadania, „od kiedy grota [7] nie była użytkowana” i czy istnieje „związek poszczególnych przedmiotów znalezionych w 7Q z papirusami”. I tu, co ciekawe, postawił zgrabną propozycję. Biorąc pod uwagę dobre skomunikowanie z Rzymem i obrotność Żydów, zapytywał, „czy tajemniczy napis na dzbanie RWM’ nie może wskazywać na proweniencję papirusu - Roma?’. Ks. Chmiel pisze:

Jesteśmy w stanie wyobrazić sobie, że kumrańczycy w jakiś sposób przechwycili (zakupili, otrzymali) nowy papirus o znanym im (przynajmniej w tradycji ustnej) Jeszua Ben Josef i zachowali w swoim archiwum, dając mu sigla „katalogowe” ROMA.

Innymi słowy ks. Chmiel nie obawiał się przesunięcia datowania tekstu Ewangelii św. Marka na okres przed rokiem 50 po Chrystusie, akceptując „możliwość wczesnego datowania [jej] ostatecznej redakcji”. Warto podkreślić, jak trafna była propozycja przebadania raz jeszcze groty 7. Podczas jednego z kolejnych międzynarodowych kolokwiów qumranologicznych ta sprawa powróciła. W trakcie sympozjum Christen und Christliches in Qumran (Eichstätt 1991) ${ }^{17}$ m.in. za sprawą prof. Jamesa Charleswortha podjęto inicjatywę sformowania specjalnej ekspedycji archeologicznej. ${ }^{18}$ Niestety w międzyczasie grota 7 zsunę-

17 Por. B. Mayer, C. P. Thiede, Qumran-Tagung in Eichstätt, „The Qumran Chronicle” 2 (1993) nr 2, s. 97-100.

18 Por. Z. J. Kapera, The Eichstätt Symposium: „The Texts from Cave Seven. Christians and Christianity in Qumran?”, „The Qumran Chronicle” 2 (1993) nr 2, s. 91-96. 
ła się do wąwozu Wadi Qumran. ${ }^{19}$ Można tylko ubolewać, że artykuł z sugestią ks. Chmiela nie ukazał się także w języku obcym.

O poważnym zainteresowaniu sprawą ewentualnego znalezienia papirusu z Ewangelią św. Marka świadczy fakt, że ks. Jerzy Chmiel wrócił do tego problemu raz jeszcze po ponad dwudziestu latach w „Ruchu Biblijnym i Liturgicznym”20. Zamieszczony tam kolejny artykuł pokazuje, jak bardzo pasjonował go ten problem i jak celnie wartościował argumenty uczonych wypowiadających się w kwestii identyfikacji i datowania zwoju. Wyliczył argumenty papirologiczno-paleograficzne i krytyki tekstualnej przemawiające za hipotezą o. O’Callaghana. Wskazał na obiektywne trudności w datowaniu fragmentu 7Q5, tj. zsunięcie się groty do wąwozu i zbyt małą powierzchnię zachowanego papirusu, aby pobrać próbki do badań węglem radioaktywnym C14. Nie wyraził jednak obiekcji odnośnie wczesnego datowania Ewangelii św. Marka. Podsumowując, odniósł się do zasady falsyfikacji (fallibilizmu) i stwierdził: „można powiedzieć, że w naszym przypadku sprawdzania wiarygodności odczytania 7Q 5 propozycja O’Callaghana zawiera wiele potencjalnych falsyfikatorów, które nadają jej większy stopień prawdoupodobnienia, donec contraria demonstrentur”21. Jak już wzmiankowałem, dziś nadal papirus 7Q5 budzi zainteresowanie, a kwestia jego identyfikacji nadal pozostaje nierozwiązana ${ }^{22}$.

19 Nie zachowała się nawet fotografia groty 7. Zob. fotografię klifu z zaznaczonym miejscem groty 7: J. B. Humbert, Cacher et se cacher a Qumran: Grottes et refuges. Morphologie, fonctions, antropologie, [w:] The Caves of Qumran, ed. by M. Fidanzio, Brill, Leiden-Boston 2017, s. 50, fig. 2.14, a także fig. 2.15, https://doi.org/10.1163/9789004316508.

20 J. Chmiel, Zagadka rękopisu Ewangelii św. Marka z groty 7, „Ruch Biblijny i Liturgiczny” 48 (1995) nr 3, s. 182-186, https://doi.org/10.21906/rbl.3415.

21 Tamże, s. 186.

22 Do problemu papirusu 7Q5 na polskim gruncie ustosunkowała się po ks. Chmielu również Magdalena Marzec w dwóch artykułach: Ewangelia św. Marka w Qumran? oraz Prezentacja badań nad fragmentem 7Q5, [w:] Z badań nad Biblia, red. T. Jelonek, t. 4, Wydawnictwo UNUM, Kraków 2002, s. 197-216 oraz Metody badawcze 7Q5, [w:] Z badań nad Biblia, red. T. Jelonek, t. 5, Wydawnictwo Naukowe Papieskiej Akademii Teologicznej w Krakowie, Kraków 2002, s. 191-202. Nawiązał do niego także Sławomir Stasiak w artykule: Alcune scoperte bibliche, [w:] Żyjemy dla Pana. Księga pamiątkowa dedykowana S. Profesor Ewie Józefie Jezierskiej OSU w siedemdziesiątą rocznicę urodzin, red. M. Rosik, Papieski Wydział Teologiczny we Wrocławiu, Wrocław 2005, s. 661-664. 
Wracając do wzmiankowanej współpracy ks. Jerzego Chmiela z Komisją Orientalistyczną Polskiej Akademii Nauk w Krakowie chciałbym dodać, że pomimo skromnych możliwości Komisji można było jednak co roku zaprosić do Krakowa dwie osoby z zagranicy. Choć pierwszeństwo mieli orientaliści sensu stricto, to jednak wielokrotnie proponowałem, aby zapraszać także biblistów. Sprzyjała temu życzliwość prof. dra hab. Tadeusza Lewickiego, wieloletniego przewodniczącego Komisji, a zarazem kolegi i przyjaciela ks. prof. Aleksego Klawka jeszcze z okresu lwowskiego (sprzed roku 1939). W latach siedemdziesiątych Kraków wizytowali m.in. prof. Edward Lipiński z Uniwersytetu w Lovanium, prof. André Lemaire, prof. Marc Philonenko, ks. prof. Jean Carmignac oraz ks. prof. Mathias Delcor. Wszyscy oni m.in. interesowali się i publikowali prace w zakresie qumranologii. Ks. prof. Chmiel nie tylko bywał obecny na ich wykładach, ale także, np. w przypadku ks. Carmignaca, zapraszał ich z dodatkowym wykładem do seminarium duchownego.

Szczególnie efektywna współpraca Komisji Orientalistycznej i księdza Chmiela jako reprezentanta Papieskiej Akademii Teologicznej miała miejsce podczas międzynarodowych konferencji qumranologicznych organizowanych przeze mnie w oparciu o Komisję Orientalistyczną. Ponieważ pierwsze spotkania odbyły się w Mogilanach pod Krakowem, to w literaturze naukowej są znane jako „Mogilany colloquia”. Miały one miejsce w latach 1987, 1989, 1991, 1993, 1995 i zakończyły się jako jedna z sekcji w ramach 16. Międzynarodowego Kongresu Society of Biblical Literature w Krakowie w roku 1998. Ks. Chmiel wziął czynny udział w czterech kolokwiach mogilańskich. Wygłosił trzy referaty, które nie tylko wzbudziły zainteresowanie uczestników, ale pośrednio wskazały na kierunki badań, którymi faktycznie podążyła qumranologia.

Zanim omówię wygłoszone przez niego referaty, chciałbym wyrazić wdzięczność za praktyczną pomoc udzieloną mi wtedy przez ks. Chmiela. Otóż prawdziwym i miłym zaskoczeniem dla mnie jako organizatora było przybycie wielu polskich biblistów reprezentujących wszystkie ważniejsze ośrodki w naszym kraju ${ }^{23}$. To niesłychanie wzbo-

23 Por. fotografie w „Folia Orientalia” 25 (1988), wklejka po s. 4. 
gaciło atmosferę spotkania w roku 1987, ożywiło dyskusje i pozwoliło z ufnością przygotować kolejne spotkania. Przy okazji chciałbym przytoczyć krótką anegdotę. Mogilany, które wówczas wydawały się odległe od Krakowa o wiele bardziej niż dzisiaj, przeżyły dwukrotny szok. Po pierwsze, zobaczyli po raz pierwszy od wojny prawdziwego ortodoksyjnego Żyda (chodzi o prof. Lawrence’a Schiffmana z Nowego Jorku), a na następnego dnia - najliczniejszą koncelebrę w dziejach kościoła św. Bartłomieja w Mogilanach. Tak więc dzięki życzliwej rekomendacji kolokwiów mogilańskich przez ks. Chmiela w kręgu polskich biblistów mogliśmy się spotkać aż sześciokrotnie.

Podczas kolokwium w roku 1987 ks. Chmiel wygłosił w języku francuskim referat nt. świadomości wspólnoty qumrańskiej i jej sekciarskiej postawy (La conscience de communauté et l'attitude sectaire à Qumran) ${ }^{24}$. Wychodząc z definicji hermeneutyki i pojęcia „świata tekstu” Paula Ricoeura, dokonał przeglądu pojęć określających wspólnotę z Qumran: thiasos (mrzh'), haburah i yahad. Dla Greków według ks. Chmiela z pewnością społeczność qumrańska była jedną z tiaz. Jednakże bractwo qumrańskie miało wewnętrznie inny charakter niż organizacje pogańskie. Qumrańczycy nie spożywali np. posiłków wobec bóstw, lecz według 1QSa II, 8-9 w obecności niewidzialnych aniołów. Ich uczty sakralne wykształciły się w typ haburah - bractwa paschalnego. Świętowanie Paschy izraelskiej musiało wywrzeć znaczny wpływ na mentalność zgromadzenia, ale była to Pascha duchowa. Nie odnaleziono ołtarza w Chirbet Qumran, a znalezione resztki zwierzęce trudno byłoby zinterpretować jako pozostałości wspólnej ofiary ${ }^{25}$. Analogicznie do duchowej Paschy znajdujemy w doktrynie qumrańskiej pojęcie świątyni duchowej jako substytutu świątyni w Jerozolimie. Terminem, który

24 J. Chmiel, La conscience de communauté et l'attitude sectaire à Qumran. Remarques herméneutiques, „Folia Orientalia” 25 (1988): The first International Colloquium on the Dead Sea Scrolls (Mogilany near Cracow: May 31-June 2, 1987), s. 137-142 i anglojęzyczne streszczenie: The Conscience of the Qumran Community, „Sprawozdania z Posiedzeń Komisji Naukowych Polskiej Akademii Nauk Oddział w Krakowie” 31 (1987) nr 1, s. 82. 25 Aktualnie Jodi Magness próbuje jednak przekonać, że Esseńczycy składali ofiary w Chirbet Qumran. Propozycja ta została przedyskutowana na specjalnej sesji w trakcie międzynarodowego spotkania Society of Biblical Literature w Buenos Aires w roku 2015. Referaty te można znaleźć w „Journal of Ancient Judaism” 7 (2016) nr 1, s. 1-135. 
określa wspólnotę, jest yahad, słowo oznaczające w Biblii „zbierać się”, co tutaj określa zorganizowane zgromadzenie qumrańczyków w monasterze, wspólnotę cenobitów. Charakteryzuje tę wspólnotę kilka rytuałów: chrzest inicjacyjny integrujący neofitę ze zgromadzeniem, który powtarzany był jako coroczne obmycia rytualne; wspólne posiłki pojmowane jako antycypacja uczty mesjańskiej; ascetyzm gminy (celowa rezygnacja z małżeństwa) i wreszcie apokaliptyczna metoda hermeneutyczna. Dookreślając wspólnotę jako sektę, ks. Chmiel zwraca uwagę na podtrzymanie i wzmocnienie przez nią separatyzmu kapłańskiego oraz wykluczenie z bankietu mesjańskiego wszystkich nieczystych oraz kalek, zarówno fizycznych, jak i psychicznych.

Warto zwrócić uwagę na jeszcze jeden element rozważań ks. Chmiela. Otóż widział on w ewolucji poglądów zrzeszenia także wpływ rodzącego się chrześcijaństwa. Akcentował tu wzmiankę z Dziejów Apostolskich 6, 7, gdzie jest mowa o wielu kapłanach, którzy przyjęli wiarę. Przypuszczał, że byli to Esseńczycy. I wreszcie na koniec, oceniając dotychczasowe studia nad znaczeniem i treścią teologiczną głównych pojęć doktryny sekty (np. berît, šûb i hesed), ks. Chmiel sformułował ważny postulat badawczy. Według niego należało zwrócić większą uwagę na badanie pól semantycznych niektórych pojęć z Qumran. Ponieważ problemem centralnym hermeneutyki jest metafora, to należy pamiętać, że „świat tekstu” z Qumran nie jest językiem potocznym. Jednakże tylko przez ten język możemy poznawać świat esseńskiej wspólnoty ${ }^{26}$. Wskazany postulat badawczy ks. Chmiela został spełniony dopiero w ostatnich kilku latach dzięki publikacji teologicznego słownika tekstów qumrańskich zredagowanego przez Heinz-Josefa Fabry’ego i Ulricha Dahmena ${ }^{27}$.

Również w roku 1989 ks. Chmiel wziął czynny udział w kolejnym mogilańskim spotkaniu poświęconym rękopisom znad Morza Martwego. Zabierał głos w trakcie dyskusji nad przyszłością badań nad zwojami i poparł zaproponowaną przeze mnie, a zredagowaną przez profesorów

26 Streszczenie tego referatu zamieściłem w artykule pt. Aktualny stan badań nad tekstami z Qumran, „Euhemer” 30 (1989) nr 2-4, s. 55-56.

27 Por. Theologisches Wörterbuch zu den Qumrantexten, hrsg. H.-J. Fabry, U. Dahmen, t. 1-3, Kohlhammer, Stuttgart 2011-2016. 
Maxa Wilcoxa i Philipa Daviesa tzw. Rezolucję Mogilańską ${ }^{28}$, nawołującą do szybkiego udostępnienia tekstów groty 4 znajdujących się w rękach zaledwie ośmiu uczonych. Choć nie można zdecydowanie powiedzieć, że podjęcie tej rezolucji miało przełomowe znaczenie dla uwolnienia zwojów, to jednak, jak zauważył ks. prof. Joseph A. Fitzmyer SJ, m.in. ta rezolucja spowodowała wówczas wzrost zainteresowania rękopisami qumrańskimi i zwróciła uwagę na „wzrastającą wszędzie niecierpliwość uczonych z powodu opóźnień edytorskich” ${ }^{29}$. Uważam jednak, że właśnie po mogilańskiej rezolucji wkrótce przyszło burzliwe spotkanie w Princeton, potem kolejna rezolucja w Long Beach (Kalifornia) i w efekcie nastąpiła lawina zdarzeń ${ }^{30}$, które doprowadziły ostatecznie do ogłoszenia w listopadzie 1991 roku przez prof. Emanuela Tova wolnego dostępu do fotografii zwojów wszystkim zainteresowanym. Jego wystąpienie miało miejsce w trakcie dorocznego spotkania Society of Biblical Literature w Kansas City ${ }^{31}$. Miło to przypomnieć, gdyż w procesie tym swój udział zaznaczył ks. Jerzy Chmiel, zdecydowanie popierając Rezolucję Mogilańską swoim autorytetem profesora Papieskiej Akademii Teologicznej w Krakowie.

Podczas konferencji w 1989 roku ks. Jerzy Chmiel wygłosił kolejny, zwięzły i treściwy referat na temat zwojów qumrańskich w świetle

28 P. Davies, Z. J. Kapera, M. Wilcox, The Mogilany Resolution 1989, „Folia Orientalia” 26 (1989), s. 229-230. Tekst ten przedrukowano także w „The Qumran Chronicle” 1 (1990-1991) nr 1, s. 10-12 oraz w Mogilany 1989. Papers on the Dead Sea Scrolls offered in memory of Jean Carmignac, red. Z. J. Kapera, t. 1, The Enigma Press, Kraków 1993, s. 15-16. Zob. też: H. Shanks, Polish Conference: Resolution Calls for Release of the Dead Sea Scrolls, „Biblical Archaeology Review” (1990) nr 1, s. 10 i reprint w „The Qumran Chronicle” 1 (1990-1991) nr 1, s. 13-15.

29 Por. J. A. Fitzmyer, 101 pytań o Qumran, WAM, The Enigma Press 1997, s. 168-169.

30 Por. Z. J. Kapera, The Impact of the Mogilany Resolution 1989, [w:] Mogilany 1989..., dz. cyt., t. 1, s. 225-228 oraz Z. J. Kapera, The Unfortunate Story of the Qumran Cave Four, „The Qumran Chronicle” 1 (1990-1991) nr 2-3, s. 40-53. Zob. także M. Baigent, R. Leigh, Zwoje znad Morza Martwego. Historia pewnego oszustwa, Da Capo, Warszawa 1994, s. 143-148; A. J. Palla, Sekrety Biblii, Betezda, Rybnik 2002, s. 216-218.

31 E. H. Lovering, In Dead Sea Scrolls Session SBL Issues a Statement on Access to Ancient Written Materials, „Religious Studies News” 7 (1992) nr 1, s. 3-5; Z. J. Kapera, The Scrolls Debates in Kansas City, MO (November 1991), „The Qumran Chronicle” 2 (1993) nr 2, s. 108-112. 
teorii komunikacji ${ }^{32}$. Uwzględniając ogromny materiał (ponad osiemset zwojów ${ }^{33}$ ), zwrócił uwagę na fakt, że - stosując terminologię teorii komunikacji - zwoje jako takie są głównym medium przekazywania nauk we wspólnocie qumrańskiej. Fenomen ten jest związany z innym ówczesnym fenomenem, który w nauce znany jest jako „targumizm”. Termin ten wprowadzony został przez Le Déaut’a. W dobie istnienia wspólnoty qumrańskiej powstawały tłumaczenia na język aramejski lub nawet parafrazy Tory dokonywane przez interpretatorów zwanych „meturgemanami”. Owi palestyńscy meturgemani mogli być członkami różnych sekt, także sekty esseńskiej, w tym szczególnie qumrańskiej grupy interpretatorów Biblii. Mogli oni, zgodnie z regułą hermeneutyczną, wprowadzać swoje własne idee eschatologiczne, dualistyczne czy mesjanistyczne do tłumaczeń Tory.

Następnie ks. Chmiel zwrócił uwagę na fakt, iż z biegiem czasu zwój jako taki staje się kryterium wyróżniającym Qumran od chrześcijaństwa. Wspólnota qumrańska wybrała zwój jako formę komunikacji swej doktryny, idąc za tradycją biblijnego Izraela, gdzie zwój był podstawowym sposobem pisemnej rejestracji doświadczenia religijnego. Można by więc nazwać członków sekty qumrańskiej „synami zwojów”. Zwoje stały się dla nich kryterium kontynuacji, bo łączyły ze Starym Testamentem, i braku ciągłości, bo kodeks rozpoczyna w nową epokę epokę Nowego Testamentu ${ }^{34}$.

Ze względu na swoje rozliczne obowiązki służbowe ks. Jerzy Chmiel nie brał udziału w trzecim i czwartym kolokwium qumranologicznym, ale przybył na spotkanie w roku 1995, tym razem w Krakowie na Zakrzówku. Wygłosił wtedy referat na temat, jaki

32 J. Chmiel, Sons of the Scrolls. Some Reflections on the Dead Sea Scrolls from the Aspect of Communication Theory, [w:] Mogilany 1989..., dz. cyt., t. 1, s. 31-35.

33 Dziś ocenia się, że ich liczba zbliżona jest do tysiąca. Zob. D. Dimant, History, Ideology and Bible Interpretation in the Dead Sea Scrolls. Collected studies, Mohr Siebeck, Tübingen 2014, s. 1.

34 Por. streszczenie tego wykładu: J. Chmiel, Sons of the Scrolls. Some reflections on the Dead Sea Scrolls from the viewpoint of communication theory, „Sprawozdania z Posiedzeń Komisji Naukowych Polskiej Akademii Nauk Oddział w Krakowie” 33 (1989) nr 2, s. 28 i reprint w „The Qumran Chronicle” 1 (1990) nr 1, s. 28-29. 
rodzaj hermeneutyki jest przydatny dla interpretacji tekstów z Pustyni Judzkiej $^{35}$. Przypominając praktyczne znaczenie hermeneutyki jako klucza do interpretacji zwojów, ks. Chmiel zaproponował model hermeneutyki o trzech podstawowych elementach-paradygmatach:

1. Hermeneutykę historyczno-krytyczną i wskazywał na dokument Papieskiej Komisji Biblijnej o interpretacji Pisma Świętego w Kościele z 1993 roku, cytując: „Metoda historyczno-krytyczna jest nieodzowna dla naukowych badań nad znaczeniem tekstów starożytnych”. Ten bowiem rodzaj hermeneutyki bierze pod uwagę zarówno ewaluacje odkryć archeologicznych, jak i analizę nowych tekstów.

2. Hermeneutykę tekstu obejmującą zarówno elementy filologiczne, jak i jego analizę strukturalną. Idąc za Paulem Ricoeurem, ks. Chmielowi chodzi o „cały świat tekstu” (le monde du texte).

3. Hermeneutykę tekstów narracyjnych w badaniach historycznych. Nie ulega wątpliwości, że narracja jest problemem kluczowym w interpretacji tekstów (herméneutique des rapports entre récit et historie $)^{36}$.

Konkludując swoje rozważania, ostrzegał, aby nie wpaść w badaniach nad zwojami w przestrzeń między Scyllą historycyzmu a Charybdą peszaryzmu (tj. rodzaju hebrajskiego komentarza midraszowego) ${ }^{37}$. Patrząc z perspektywy badań nad historią dziejów i teologią wspólnoty z Qumran, nie sposób dziś nie przyznać racji ostrzeżeniom ks. Chmiela. Tę przestrzeń między Scyllą historycyzmu a Charybdą peszaryzmu próbuje się nadal wypełnić, ale trudno stwierdzić, aby qumranologowie doszli do definitywnych wniosków na temat osiedla qumrań-

35 J. Chmiel, Quelle herméneutique est utile pour interpreter les texts du désert de Juda?, [w:] Mogilany 1995. Papers on the Dead Sea Scrolls offered in memory of Aleksy Klawek, ed. by Z. J. Kapera, The Enigma Press, Kraków 1998, s. 117-121 oraz streszczenie angielskie: What kind of hermeneutics is useful for the Dead sea Scrolls, „Sprawozdania z posiedzeń Komisji Naukowych Polskiej Akademii Nauk Oddział w Krakowie” 39 (1995) nr 1, s. 109-110.

36 J. Chmiel, Quelle herméneutique..., dz. cyt., s. 120.

37 Por. streszczenie referatu ks. Jerzego Chmiela w artykule: B. Wodecki, Piąte międzynarodowe colloquium qumranologicum w Krakowie (1995), „Komunikaty SVD” $1995 \mathrm{nr}$ 8, s. 206-207 i przedruk: B. Wodecki, Na początku było słowo, t. 1, Pieniężno 2005, s. 990-991. 
skiego ${ }^{38}$ czy odtworzenia doktryny wspólnoty, bo o tym, że pośród setek zwojów bardzo dużo tekstów nie jest wcale autorstwa esseńczyków, wiemy już od dwóch dekad ${ }^{39}$.

Ks. Jerzy Chmiel głosił swoje hermeneutyczne uwagi o zwojach nie tylko w ramach kolokwiów mogilańskich. W roku 1995 w trakcie ogólnopolskiego sympozjum biblistów w czterdziestopięciolecie odkryć nad Morzem Martwym referował niektóre aspekty dyskusji o stosunku chrześcijaństwa do Qumran. Skoncentrował się na dwóch kluczowych aspektach: na analizie problemu Jezus a Esseńczycy w powieściach biograficznych jako schemacie interpretacyjnym oraz na przedstawieniu propozycji modelu hermeneutycznego dla analizy porównawczej tekstów z Qumran i Nowego Testamentu. W pierwszym przypadku zwrócił uwagę na „ciekawy antecedens wiązania chrześcijaństwa z Qumran jako pewien schemat interpretacyjny” wychodząc od faktu łączenia Jezusa z Esseńczykami od okresu oświecenia, tj. od publikacji sławnej vies romancées Jezusa pióra Karla Friedricha Bahrdta (1741-1792), a kończąc na „współczesnej baśni o Jezusie qumrańczyku” Barbary Thiering $^{40}$. Dla ks. Chmiela nie ulega wątpliwości, że te „vies romancées Jezusa tradycji niemieckiej wywarły wpływ na sposób myślenia zwłaszcza badaczy strefy języka niemieckiego”. Tłumaczy, dlaczego wiązano „życie Jezusa z tradycją esseńską”. Ma to związek po pierwsze, z rozwojem filologii klasycznej i znajomości źródeł hellenistycznych i łacińskich. Po drugie, z podziwem dla stylu życia Esseńczyków, imponującemu

38 Por. Z. J. Kapera, Archeologia Chirbet Qumran (1958-2007), „Studia Judaica” 10 (2007), s. 153-183 oraz z najnowsze publikacje: D. Stacey, G. Doudna, Qumran Revisited: A Reassessment of the Archaeology of the Site and Its Texts, Archaeopress, Oxford 2013. Finalna publikacja ruin Chirbet Qumran rozpoczęta przez J. B. Humberta w roku 1994 jest daleka od ukończenia, choć ukazał się w roku 2016 tom 3A w serii Khirbet Qumran et Ain Feshkha. Przy aktualnym tempie publikacji pełny materiał będzie dostępny za kilka dekad.

39 Już nawet Devorah Dimant (History, Ideology and Bible Interpretation in the Dead Sea Scrolls. Collected studies, dz. cyt., s. 21-23) wyraźnie wyróżnia dwie duże grupy tzw. „the nonsectarian texts": utwory parabiblijne i pisma aramejskie.

40 Por. B. Thiering, Jesus and the Riddle of the Dead Sea Scrolls, Harper, San Francisco 1992. Por. „The Qumran Chronicle” 5 (1995), s. 1-84: Barbara Thiering and recent research on Jesus, w którym pomieszczone jest angielskie tłumaczenie omawianego wykładu ks. Jerzego Chmiela (Christianity and Qumran, s. 46-54). 
niemieckiemu Ordnung. Po trzecie, z tendencją apokryficzną, uzupełniającą brakujące elementy biografii Jezusa. Po czwarte, stwierdzenie związku Jezusa z sektą esseńską dawało „ważny argument w zwalczaniu chrześcijaństwa, które nie jest oryginalne, lecz powiela wcześniejsze poglądy z łona judaizmu”41. Podobną rolę w powielaniu tego poglądu odegrały w Polsce pisma „Euhemer” i „Argumenty” w latach pięćdziesiątych, sześćdziesiątych i siedemdziesiątych XX wieku. Pytanie, czy istniało chrześcijaństwo przed Chrystusem, pojawiało się wtedy nie tylko w tych czasopismach, ale i w prasie codziennej ${ }^{42}$. Zresztą to ogólne spostrzeżenie ks. Chmiela dotyczy zarówno tzw. krajów socjalistycznych, jak i przede wszystkim Zachodu, gdzie niepodzielnie brylowały szczególnie w prasie lat pięćdziesiątych poglądy prof. André DupontSommera i Johna Marco Allegro, a o Qumran mówiło się za Edmundem Wilsonem, że była to prawdziwa kolebka chrześcijaństwa ${ }^{43}$.

Tym razem ks. Chmiel wypowiedział się w kwestii kryteriów właściwego objaśniania tekstów znad Morza Martwego. Przede wszystkim przestrzegał przed wyszukiwaniem i przecenianiem paralel rzeczywistych lub tylko potencjalnych, wskazując, że w żadnym wypadku nie muszą one świadczyć o wspólnym genetycznym pochodzeniu tekstów. Uważał, że „istnienie tekstów podobnych samo z siebie nie przesądza, że tekst B pochodzi od tekstu A. Należy wykazać genetyczne pochodzenie tekstów przy pomocy innych kryteriów, jak: kontekst, środowisko, uwarunkowania zewnętrzne, świadectwo osób trzecich itd.”44 Nie wykluczał zapożyczeń, ale według niego w grę wchodzi sfera językowa, a nie ideowa. I znów trzeba zaznaczyć, że był to bardzo wybiegający naprzód pogląd, o czym może świadczyć fakt, że w podobnym duchu zdecydowanie wypowiedział się Jörg Frey w oksfordzkim podręczniku do zwojów z roku 2010, a więc piętnaście lat później ${ }^{45}$.

41 Por. J. Chmiel, Chrześcijaństwo a Qumran, „Collectanea Theologica” 65 (1995) fasc. 1, s. 69-71.

42 Por. Z. J. Kapera, Polska bibliografia rękopisów znad Morza Martwego, „Euhemer” 12 (1968) $\mathrm{nr}$ 2, s. 129-140.

43 E. Wilson, Odkrycia nad Morzem Martwym, Książka i Wiedza, Warszawa 1963.

44 J. Chmiel, Chrześcijaństwo a Qumran, dz. cyt., s. 72.

45 Por. J. Frey, Critical issues in the investigation of the scrolls and the New Testament, [w:] The Oxford Handbook of the Dead Sea Scrolls, ed. by T. H. Lim, J. J. Collins, Oxford University 
W tym samym wystąpieniu ks. Chmiel poruszył także problem stosunku Jezusa do Qumran, innymi słowy: czy Jezus znał qumrańczyków. Wydawało mu się mało prawdopodobne, aby Jezus nie słyszał o esseńczykach i o ich osiedlu. Uważał, że „nie powinniśmy się bać tego, że Jezus mógłby mieć kontakty z qumrańczykami, a nawet, że mógłby przebywać czas jakiś w Qumran!”. Dostrzegał ślady kontaktów Jezusa z wspólnotą z Pustyni Judzkiej, zestawiając np. Mt 5, 43 z 1QS 1, 9-10; 9, 21-22) odnośnie do nienawiści nieprzyjaciół; Mt 5, 48 z 1QS 1, 8 czy 1QS 2, 2 i 3, 9 odnośnie do boskiego tytułu „doskonały” czy Mt 7, 13-14 z 1QS 3, 20-21 odnośnie do dwóch dróg. Wreszcie perykopy synoptyków o kuszeniu Jezusa na pustyni mogłyby być według ks. Chmiela „reminiscencją qumrańskiego doświadczenia Jezusa”46.

W nawiązaniu do ówczesnych dyskusji ks. Chmiel zwrócił też uwagę „na trzy parametry badań intertekstualnych Q[umran] - N[owy] T[estament]":

1. Na konieczność „prawidłowego odczytania tekstów qumrańskich”, tzn. „bez supozycji, że w Qumran już były obecne idee chrześcijańskie”.

2. Na niezbędną „nową rewaloryzację odkryć archeologicznych”.

3. Na przywrócenie właściwych założeń metodologicznych ${ }^{47}$.

I obecnie znów stwierdzamy, że dezyderaty ks. Chmiela miały uzasadnienie. Aktualnie naciągane i bazujące na indywidualnej metodologii teorie odnośnie do relacji Qumran-Nowy Testament rzeczywiście wygasają, a ostatnio odnowiła się dyskusja nad obiektami archeologicznymi z Chirbet Qumran. Na koniec ks. Chmiel przypomniał, że „teologiczna zasada synkatabazy ma jak najbardziej zastosowanie do analiz porównawczych Q[umran]-N[owy] T[estament]”48. Biorąc pod uwagę

Press, Oxford 2010, s. 527-528, https://doi.org/10.1093/oxfordhb/9780199207237.001.0001.

46 J. Chmiel, Chrześcijaństwo a Qumran, dz. cyt., s. 74-75.

47 Tamże, s. 75.

48 Tamże, s. 76-78. Zob. także krótkie omówienia tego referatu ks. Jerzego Chmiela przez Bernarda Wodeckiego, Na początku było słowo, dz. cyt., t. 1, s. 988-989 oraz przez Waldemara Chrostowskiego, 45 Years of Qumranology. 32nd Symposium of Polish Biblical Scholars Częstochowa, September 15-16, 1994, „Collectanea Theologica” 65 (1995) nr 1, s. 114-115. 
ten cykl wykładów na temat hermeneutyki zwojów, można tylko ubolewać, że ks. Chmiel nie kontynuował swoich rozważań teoretycznych po roku 1995.

W roku 1998 miało miejsce ostatnie mogilańsko-krakowskie kolokwium qumranologów ${ }^{49}$. Odbyło się ono w trakcie 16. Międzynarodowego Spotkania Society of Biblical Literature w dniach 19-22 września $1998^{50}$. Towarzystwo to organizuje coroczne spotkanie (tzw. Annual Meeting) w Stanach Zjednoczonych oraz zjazd biblistów w jednym z krajów świata (tzw. International Meeting) mający na celu promocję studiów biblijnych. Kongres krakowski nie miałby miejsca, gdyby nie życzliwa pomoc ks. Jerzego Chmiela ${ }^{51}$. Kiedy bowiem przekazałem mu jako prorektorowi Papieskiej Akademii Teologicznej w Krakowie propozycję przygotowania logistycznego takiego zjazdu, ideę tę nie tylko zaakceptował, ale osobiście gorąco poparł ${ }^{52}$. Pełniłem wtedy tylko funkcję Sekretarza Technicznego Komisji Orientalistycznej Polskiej Akademii Nauk, prof. Tadeusz Lewicki już wtedy nie żył i nie było szans na organizację takiego spotkania w ramach PAN-u. Pomógł nam fakt, że funkcję Dyrektora Instytutu Filologii Orientalnej Uniwersytetu Jagiellońskiego pełnił wówczas dr Przemysław Piekarski zainteresowany judaistyką oraz to, że ks. Chmiel i dr Piekarski znali się od szeregu lat z posiedzeń Komisji Orientalistycznej. W czasie spotkania trójki zainteresowanych ustalono podział zadań. Ks. prof. Chmiel zobowiązał się poprzeć inicjatywę ze strony Papieskiej Akademii Teologicznej w Krakowie, dr

49 Z. J. Kapera, Qumran at the SBL in Cracow, „The Qumran Chronicle” 8 (1998), s. 9-12; Abstracts of the Qumran Papers from the SBL in Cracow, „The Qumran Chronicle” 8 (1998), s. 13-19.

50 Por. Society of Biblical Literature Sixteenth International Meeting Cracow, July 19-22, 1998, red. Z. J. Kapera, „Folia Orientalia” 34 (1998), s. 5-64.

51 Por. Z. J. Kapera, SBL at Cracow. The Sixteenth International Meeting of the Society of Biblical Literature, Cracow, July 18-22, 1998, „Folia Orientalia” 34 (1998), s. 11; Z. J. Kapera, Rev. Professor Jerzy Chmiel (1935-2016), „The Qumran Chronicle” 24 (2016), s. 6-8.

52 Pragnę z naciskiem to podkreślić, gdyż w swoich sprawozdaniach z krakowskiego spotkania SBL ks. Chmiel całkowicie pomija swoją własną rolę w przygotowaniu kongresu. Zob. J. Chmiel, Międzynarodowy Zjazd Society of Biblical Literature w Krakowie, „Ruch Biblijny i Liturgiczny” 51 (1998), s. 234-236, https://doi.org/10.21906/rbl.681; Międzynarodowy Zjazd Society of Biblical Literature (Kraków 18-22 VII 1998), „Studia Judaica” 1 (1998), s. 267-268. 
Piekarski ze strony Uniwersytetu Jagiellońskiego, na mnie składając ciężar praktycznego przygotowania kongresu. Jesienią 1996 roku do Krakowa przybył prof. Kent Richards, dyrektor wykonawczy Society of Biblical Literature, który odbył spotkania z władzami obu uczelni. Dzięki życzliwości ich rektorów uzyskano dostęp do odpowiedniej infrastruktury, ks. dr Roman Bogacz umożliwił wykorzystanie Instytutu Jana Pawła II na posiedzenie inauguracyjne, natomiast dyrektor Muzeum Archeologicznego udostępnił piękny ogród na końcowe spotkanie towarzyskie. W krakowskim kongresie biblijnym wzięło udział niemal dwustu uczonych z całego świata, w tym członkowie nie tylko Society of Biblical Literature, ale także American Academy of Religion i rodzącego się European Association of Biblical Studies. Miłym akcentem spotkania inauguracyjnego było wręczenie przez prorektora ks. Chmiela medalu Merentibus Academiae prof. Richardsowi ${ }^{53}$.

Na zakończenie chciałbym dodać, że mówiąc o wkładzie ks. Chmiela w rozwój polskiej qumranologii nie sposób pominąć faktu, że napisano pod jego kierunkiem kilka prac magisterskich ${ }^{54}$ dotyczących rękopisów znad Morza Martwego, a dr Przemysław Dec pod jego kierunkiem przygotował i obronił pracę doktorską nt. zwojów Hymnów z Qumran ${ }^{55}$. Wkrótce opublikuje on Księgę Hodayot nie tylko z nowym polskim przekładem, ale przede wszystkim z całkowicie nowatorskim odczytem tekstu przy wykorzystaniu rękopisów groty 4 z Qumran ${ }^{56}$. Będzie to pierwsze tego typu opracowanie wykonane na polskim uniwersytecie. Ksiądz prof. Jerzy Chmiel był też recenzentem pracy doktorskiej

53 J. Chmiel, Opening Address, „Folia Orientalia” 39 (1998), s. 1-4.

54 M.in. A. Czachor, Nauka o dwóch duchach w Qumran, Kraków 1982; F. Tarabuła, Pojecie miłosierdzia (hesed) w pismach z Qumran $i$ w wybranych tekstach biblijnych, Kraków 1987; M. Kulig, Angelologia w Księdze Tobiasza i w pismach z Qumran, Kraków 1999. Por. prace dyplomowe napisane pod kierunkiem ks. prof. Jerzego Chmiela: W. Chrostowski, Pan moim świattem, dz. cyt., s. 43, 44 i 46.

55 P. Dec, Zwoje Hymnów Dziękczynnych znad Morza Martwego [Megillot ha-Hodajot] 1QHa [1QHb/4Q427-4Q440], Papieska Akademia Teologiczna w Krakowie, Kraków 2004, s. XVII, 301.

56 Por. P. Dec, Zwój Hymnów Dziękczynnych z Qumran (1QHodajot ${ }^{a}$ ). Rekonstrukcja - przekład - komentarz, The Enigma Press, Kraków-Mogilany 2017 oraz część druga: Hymny Dziękczynne z Qumran, The Enigma Press, Kraków-Mogilany 2020. 
Piotra Muchowskiego na temat Zwoju Miedzianego z Qumran ${ }^{57}$. Warto też wspomnieć, że ks. Chmiel współpracował przy redakcji kilku tomów z serii Biblioteka Zwojów wydawnictwa The Enigma Press, w tym przy przekładzie wszystkich zwojów znad Morza Martwego Piotra Muchowskiego ${ }^{58}$. Warto też przypomnieć, że ks. Chmiel recenzował pracę doktorską Jerzego Ciecieląga z Uniwersytetu Pedagogicznego w Krakowie. Choć dotyczyła ona politycznej historii Palestyny w okresie herodiańskim ${ }^{59}$, a nie bezpośrednio Qumran, to jednak na jej marginesie powstały unikalne na gruncie polskim publikacje Ciecieląga na temat znalezisk numizmatycznych z Chirbet Qumran ${ }^{60}$.

Na początku moich wspomnień zaznaczyłem, że ks. prof. Jerzy Chmiel nie uważał się za qumranologa, jednak qumranologię uprawiał i znaczny wkład do polskiej i światowej qumranologii wniósł. Trafnie notował jej słabe punkty i bardzo trafnie przewidywał jej ukierunkowanie i rozwój. Dla mnie osobiście było zaszczytem współpracować z nim przez kilka dekad ubiegłego wieku.

57 P. Muchowski, Zwój Miedziany (3Q15). Implikacje spornych kwestii lingwistycznych, Poznań 1993.

58 P. Muchowski, Rękopisy znad Morza Martwego Qumran - Wadi Murabba'at - Masada Nachal Chewer, The Enigma Press, wyd. 2, Kraków 2000 (wyd. 1 z 1996 roku ukazało się bez tekstów z Nachal Chewer).

59 J. Ciecieląg, Palestyna w czasach Jezusa. Dzieje polityczne, Wydawnictwo Naukowe Akademii Pedagogicznej, Kraków 2000 oraz Polityczne dziedzictwo Heroda Wielkiego. Palestyna $w$ okresie rzymsko-herodiańskim, Wydawnictwo Naukowe Akademii Pedagogicznej, Kraków 2002.

60 Por. m.in. J. Ciecieląg, Monety z tzw. osiedli esseńskich nad Morzem Martwym, [w:] Studia classica et byzantina Alexandro Krawczuk oblata, red. M. Salomon, Z. J. Kapera, Uniwersytet Jagielloński Instytut Historii, Kraków 1996. 